\title{
Pneumologia
}

\section{Alveolar proteinosis - disease with unpredictable evolution (series of clinical cases)}

Anca Macri ${ }^{1, *}$, Radu Stoica ${ }^{2}$

"“Marius Nasta”, Institute of Pneumophtysiology, Sos. Viilor no 90, 050159, Clinic 3 of Pneumology, Bucharest, Romania

Abstract

2"Marius Nasta", Institute of Pneumophtysiology, ICU, Bucharest, Romania

\section{English:}

Pulmonary alveolar proteinosis (PAP) is a rare disease, certainly underdiagnosed, characterised by the intra-alveolar accumulation of a milky fluid rich in phospholipids and lipoproteins derived from alveolar surfactant, positive in periodic acid-Schiff staining. The alveolar macrophage plays a major role in the pathogenesis of PAP, and its role in the turn-over of alveolar surfactant is being altered by various mechanisms.

More than $90 \%$ of cases of PAP are primary autoimmune, characterised by the presence in serum of circulating autoantibodies against granulocyte-macrophages colony-stimulating factor. Other causes of PAP are genetic, secondary to other diseases or to exposure to different agents.

The evolution of the disease is unpredictable, from spontaneous remission to progression despite treatment towards pulmonary fibrosis and chronic severe respiratory failure. The gold standard of therapy is the whole lung lavage, other treatments are being still in evaluation.

The article presents a few cases that illustrate different patterns in the evolution of PAP.

Keywords

alveolar proteinosis $\bullet$ evolution $\bullet$ whole lung lavage $\bullet$ GM-CSF

\section{Proteinoza alveolară - boală cu evoluție imprevizibilă (serie de cazuri clinice)}

Rezumat

Romanian:

Proteinoza alveolară (PAP) este o boală rară, în mod cert subdiagnosticată, caracterizată de acumularea intra-alveolară de fosfolipide și lipoproteine derivate din surfactantul alveolar, material pozitiv la colorația periodic acid-Schiff (PAS). Rolul principal în patogenia bolii este jucat de macrofagul alveolar, a cărui functie de turn-over al surfactantului este afectată prin diferite mecanisme patogenice. Peste $90 \%$ din cazurile de PAP sunt autoimune, caracterizate de prezența auto-anticorpilor împotriva factorului de stimulare a coloniilor de granulocite și macrofage [granulocyte-macrophages colony-stimulating factor (GM-CSF)]. Alte cauze pot fi genetice, secundare altor afecțiuni sau expunerii la agenți de mediu.

Evoluția bolii este imprevizibilă, de la remisiune spontană la progresie în pofida tratamentului către fibroză pulmonară și insuficiență respiratorie severă. Gold-standardul terapiei îl reprezintă lavajul pulmonar total [whole lung lavage (WLL)], alte tratamente fiind încă în curs de evaluare.

Articolul prezintă câteva cazuri care ilustrează diverse variante evolutive ale PAP.

Cuvinte-cheie

proteinoză alveolară • evoluție • lavaj pulmonar total • GM-CSF

${ }^{*}$ Corresponding author: Anca Macri

E-mail: ancamacriyahoo.com 


\section{Definition}

Pulmonary alveolar proteinosis (PAP) is a rare disease, first described in 1958, characterised by the intra-alveolar accumulation of a milky fluid rich in phospholipids and lipoproteins derived from alveolar surfactant, positive in periodic acid-Schiff (PAS) staining $(1,2)$.

\section{Epidemiology}

The real prevalence of the disease is not known, but data reported by different authors are around $0.2-6$ cases per $1,000,000(3,4)$. The median age is $30-50$ years, being more frequent in men (2:1 ratio) and in smokers. Genetic cause is also present in pediatric cases.

\section{Pathogenesis}

The alveolar macrophages (AMs) play a major role in the pathogenesis of PAP, and its role in the turn-over of alveolar surfactant is being altered by various mechanisms (5).

Ninety percent of PAP cases are primary autoimmune, characterised by the presence in serum of circulating autoantibodies against granulocyte-macrophages colonystimulating factor (GM-CSF) preventing the surfactant resorption by AM, with excessive accumulation in alveoli (6-9). The remaining $10 \%$ of PAP cases are either secondary to other diseases (lung infections, hematologic malignancies and AIDS) (10-12) or inhalation of silica, aluminium, titanium oxide or insecticides $(13,14)$.

Hereditary PAP occurs in neonates and children and is caused by mutations in genes encoding for the $\alpha$ or $\beta$ chains of the GM-CSF receptor (15-17).

\section{Positive diagnosis}

The symptoms of PAP are non-specific and slow: dry or mildproductive cough, dyspnoea on exertion, asthenia, malaise, low-grade fever and weight loss. Physical examination may be normal or shows end-inspiratory crackles, finger clubbing and cyanosis. One-third of the patients with PAP have no symptoms $(18,19)$.

Chest $X$-ray shows bilateral symmetric mixed alveolarinterstitial opacities, with predominance of perihilar and lower lobes, difficult to differentiate from other conditions like bronchopneumonia, pulmonary oedema, and so on (20).

High-resolution computed tomography (HRCT) of the chest shows a highly suggestive pattern for a positive diagnosis, described as "crazy-paving" - a mixture of patchy areas of ground-glass opacities with smooth interlobular septal thickening and intralobular interstitial thickening, which produces a polygonal pattern, together with areas with normal morphology. Clinicians should be aware that these aspects may be also seen in other conditions like lesional or cardiogenic pulmonary oedema, pulmonary infection (mycoplasma and pneumocystis), alveolar haemorrhage, exogenous lipoid pneumonia, mucinous bronchoalveolar cell carcinoma, and other (21-24).

The discrepancy between few and slow-progressing symptoms and impressive radiological presence is one of the keys to a positive diagnosis.

Bronchoalveolar lavage is pathognomonic, showing a milkylike fluid with increased cellularity, a high proportion of lymphocytes, large foamy macrophages with eosinophilic granules and extracellular PAS-positive globular hyaline material $(25,26)$.

Lung biopsy (either transbronchial or through video-assisted thoracoscopy) is rarely necessary; it shows intra-alveolar granular PAS-positive and diastase-resistant eosinophilic material. Electron microscopy of the material shows multilamellated structures and membranous vesicles (27).

\section{Other tests}

Anti-GM-CSF antibodies $>19 \mu \mathrm{g} / \mathrm{mL}$ are specific to autoimmune PAP; levels $<10 \mathrm{mg} / \mathrm{mL}$ have a good negative predictive value $(28,29)$. These autoantibodies may be detected at low concentrations in healthy subjects or in patients with acute myeloid leukaemia $(30,31)$. Serum $L D H$ is elevated in half of the cases. $K L-6$ (Krebs von den Lungen 6 ), a mucin-like glycoprotein, correlates well with the disease severity, and high levels predict severe evolution and need for repeated whole lung lavage (WLL) (32).

Pulmonary function tests are important for therapeutical decision and disease monitoring. The most frequent pattern is the restrictive one (although smokers can show an obstructive or mixed ventilatory dysfunction), with low diffusing capacity for carbon monoxide (DLco) (20).

In more advanced cases, blood-gas analysis shows arterial hypoxaemia with increased alveolar-arterial gradient. 6-min walking test (6MWT) shows desaturation on effort and is useful in the follow-up of patients.

\section{Evolution and prognosis}

The evolution of each case is unpredictable at the moment of diagnosis (1). 
About $15-20 \%$ of cases regress spontaneously without any treatment, others have stable disease $(\approx 50 \%)$ and the rest have multiple relapses and progressive disease. Nevertheless, since the wide use of WLL, 5-year survival with auto-immune PAP is almost $95 \%$. A minority of cases progress to interstitial fibrosis and chronic respiratory failure $(3,4)$.

The natural history of secondary PAP depends on the underlying aetiologic condition. For example, the probability of survival at 2 years has been reported to be less than $50 \%$ in cases with secondary PAP complicating haematological disorders $(11,12)$.

Patients with PAP secondary to inhalation of inorganic dust or insecticides should avoid further exposure.

As the AM function is altered in PAP, these patients have a risk of opportunistic infections, mainly with Aspergillus, mycobacteria and Nocardia (33).

\section{Treatment}

Mild cases of PAP need only follow-up with conservative measures (1).

More severe cases, with important dyspnoea on exertion, desaturation at $6 \mathrm{MWT}, \mathrm{PaO}_{2}$ at rest $<65 \mathrm{mmHg}$ and increased alveolar-arterial gradient $>40 \mathrm{mmHg}$ should receive WLL, which is considered gold standard in the therapy of PAP. It is performed under general anaesthesia, with separation of lungs (double-lumen endotracheal tube): one lung is ventilated and the other lung is washed with high amounts of a warm saline solution (15-25 L) until the fluid that comes out turns from milky to limpid. The treatment is done consecutively bilateral, 1-2 weeks apart (34-36).

In most cases, patients show symptomatic, radiographic and functional improvement after WLL, but relapses may occur, which may require repeated lavage. Patients should have regular follow-up with a pulmonologist.

In PAP secondary to other diseases WLL, although feasible, usually provides only transient benefit.

In refractory cases to repeated WLL or in those too severe to undergo this procedure, there are other treatment options with low degree of recommendation due to small number of cases and lack of randomised controlled trials: administration of recombinant GM-CSF (sargramostim and molgramostim) either through inhaled route or subcutaneous injections, aiming to stimulate the AM to eliminate the excessive surfactant (37-43); plasmapheresis and/or rituximab addressing the circulating auto-antibodies or lowering the production of these by CD20 lymphocytes (44-47).

\section{Clinical cases with different patterns of evolution}

\section{Case 1}

A 35-year-old male was admitted for fever, sweats, malaise and frequent cough with purulent sputum, starting 5 days ago. He was an active smoker of 13 pack-year. No previous dyspnoea on exertion was noted. Antibiotic treatment with oral cefuroxime was started 2 days before, with only a slight improvement of symptoms.

Physical examination was quite common, except the anterior part of the right hemithorax; end-inspiratory crackles could be heard. Saturation in oxygen in room air was in the normal range.

Chest X-ray showed bilateral perihilar opacities with predominance of lower lobes, more expressed on the right side (Figure 1).

Laboratory investigations from blood revealed leukocytosis $\left(19.300 / \mathrm{mm}^{3}\right)$ with neutrophilia $(86.2 \%)$, elevated ESR and C reactive protein, negative HIV test, normal liver and kidney parameters.

Sputum examination was negative for acid-fast bacilli, Gram stain showed neutrophils, macrophages, Gram-positive cocci and Gram-negative coccobacilli; the aerobic cultures were negative.

CT scan showed alveolar consolidation in medium lobe with air bronchogram, together with "crazy-paving" areas alternating with normal ones (Figure 2A,B).

Bronchoalveolar lavage from lingula showed rare PASpositive intra- and extra-cellular corpuscles.

Pulmonary function tests were in a normal range except DLco (51.5\% from predicted), with Kco $74.9 \%$.

The diagnosis was "Middle lobe community-acquired pneumonia; a mild form of alveolar proteinosis".

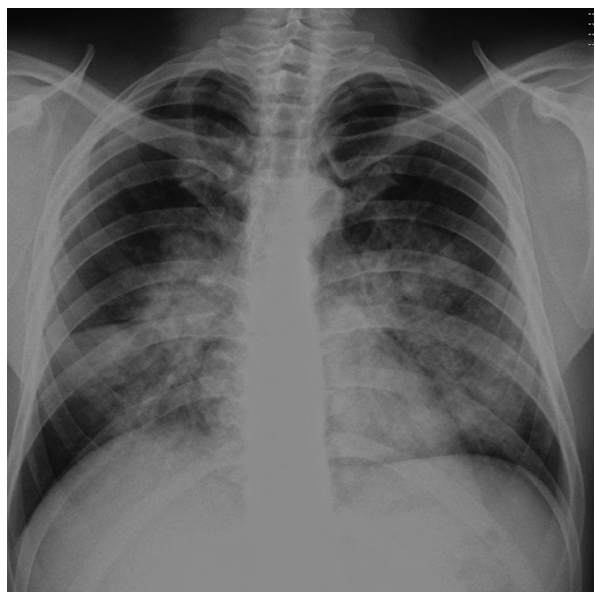

Figure 1. Case 1: Chest X-ray at admission to hospital. 

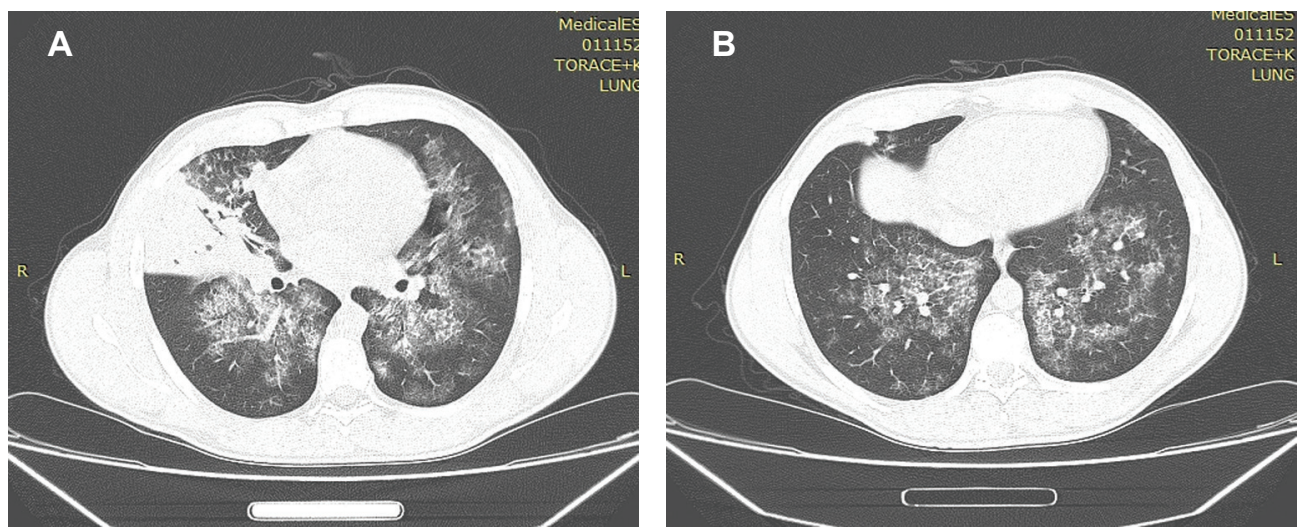

Figures 2. (A and B) Case 1: CT scan at admission to hospital.

A broad-spectrum antibiotic treatment was started (cefoperazone + sulbactam), with rapid improvement in general status and remission of fever and cough. A chest X-ray after 3 weeks showed marked remission (Figure 3 ). No indication for WLL was found, so follow-up without any treatment was the medical decision.

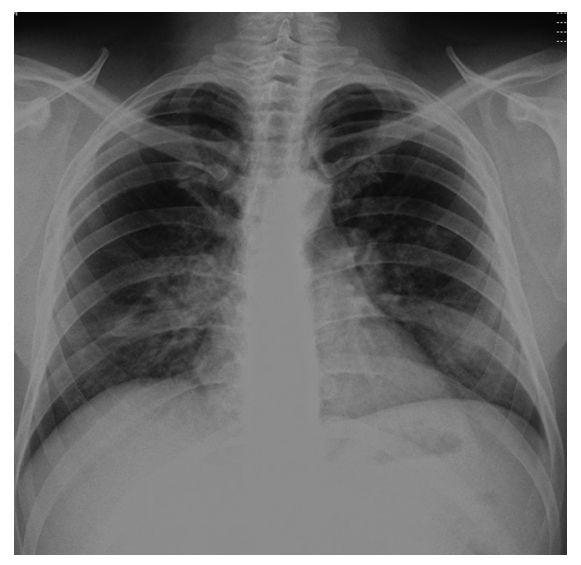

Figure 3. Case 1: Chest X-ray after 3 weeks.

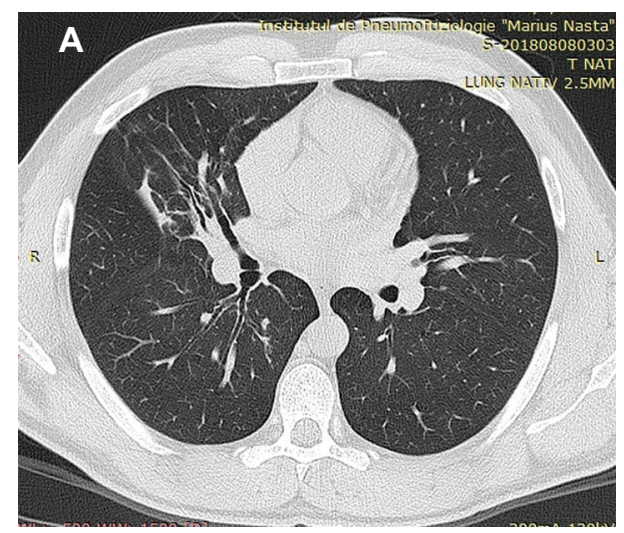

Figure 5. (A and B). Case 1: CT scan after 6 months.
After 6 months, he was evaluated again: he quit smoking, he had no respiratory symptoms, the physical examination was normal, chest X-ray and thoracic CT scan showed complete remission of crazy-paving areas with linear sequellae in median lobe (Figures 4 and $5 A, B$ ).

Conclusion in Case 1: mild PAP in infectious context, with spontaneous remission and good prognosis.

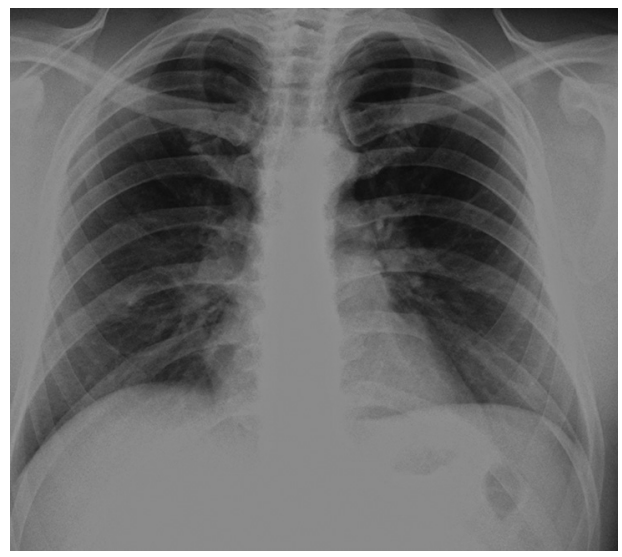

Figure 4. Case 1: Chest X-ray after 6 months.

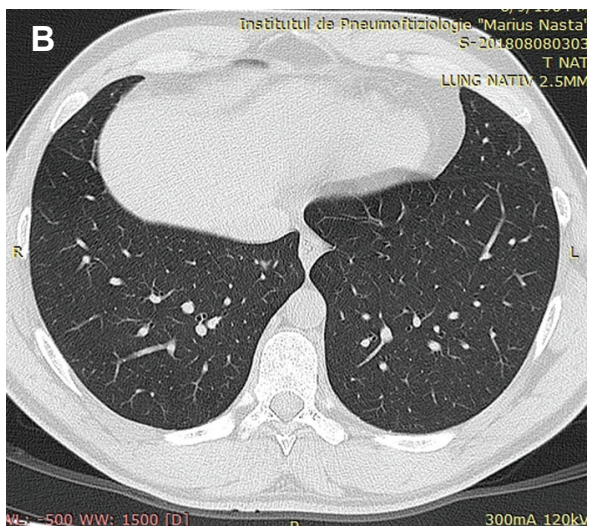




\section{Case 2}

A 34-year-old male patient, admitted for severe dyspnoea even at rest, frequent dry cough, night sweats, significant weight loss ( $\approx 15 \mathrm{~kg}$ in 12 months). The symptoms started 4 months ago, with progressive worsening. He was an active smoker of 20 pack-year and had important professional exposure to silica dust (48).

His general status was severely altered, he had cachexia $\left(\mathrm{BMI}=17 \mathrm{~kg} / \mathrm{m}^{2}\right)$, cyanosis, saturation in room air was $72 \%$, with $6 \mathrm{~L}$ of oxygen reached $90 \%$, respiratory rate was $30 / \mathrm{min}$. The chest murmur was diminished on the left thorax, and bilateral inspiratory crackles were audible.

Blood tests showed polycythaemia $(\mathrm{Hb}=18.56 \mathrm{~g} / \mathrm{dL}$; $\mathrm{Ht}=56.44 \%$ ), leukocytosis $\left(16.030 / \mathrm{mm}^{3}\right)$.

Arterial blood gases were severely altered: $\mathrm{PaO}_{2}=54.8 \mathrm{mmHg}$, $\mathrm{PaCO}_{2}=69.7 \mathrm{mmHg}, \mathrm{pH}=7.26, \mathrm{SaO}_{2}=87 \%$ (with $5 \mathrm{~L} / \mathrm{min}_{2}$ ).

The chest X-ray (Figure 6) showed "white lungs" and a partial left pneumothorax. A CT scan performed a few days before admission (Figure 7) revealed widespread "crazy-paving" with almost no normal areas, no pneumothorax.

A bronchoalveolar lavage was done despite severe hypoxaemia and showed abundant PAS-positive material, supporting the diagnosis of PAP, probably secondary to silica dust exposure.
Because of the left pneumothorax, the WLL at the moment of diagnosis was impossible. A sequential therapeutic approach was started, with surgical tube drainage of the pneumothorax as the first step. Unfortunately, the lung failed to re-expand after 30 days, with the presence of a large broncho-pleural fistula.

The next step was the surgical intervention for the suture of fistula, with very risky anaesthetic and surgical conditions (the quality of lung tissue was not known and possible risk of dehiscent sutures). The postoperative evolution was good, with re-expansion of the left lung (Figure 8).

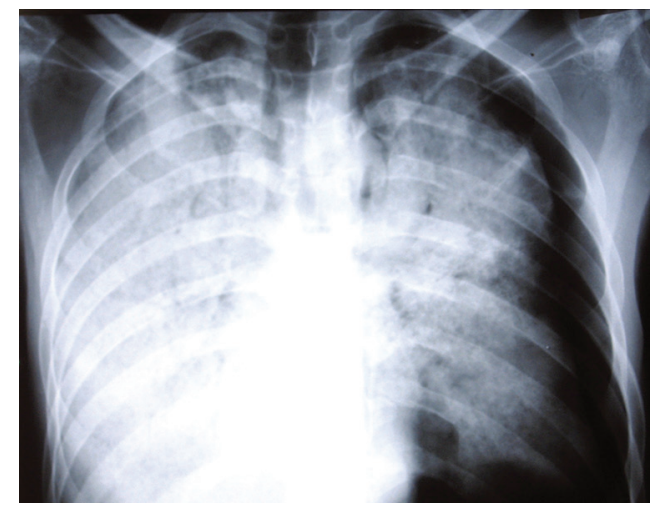

Figure 6. Case 2: Chest X-ray at admission.
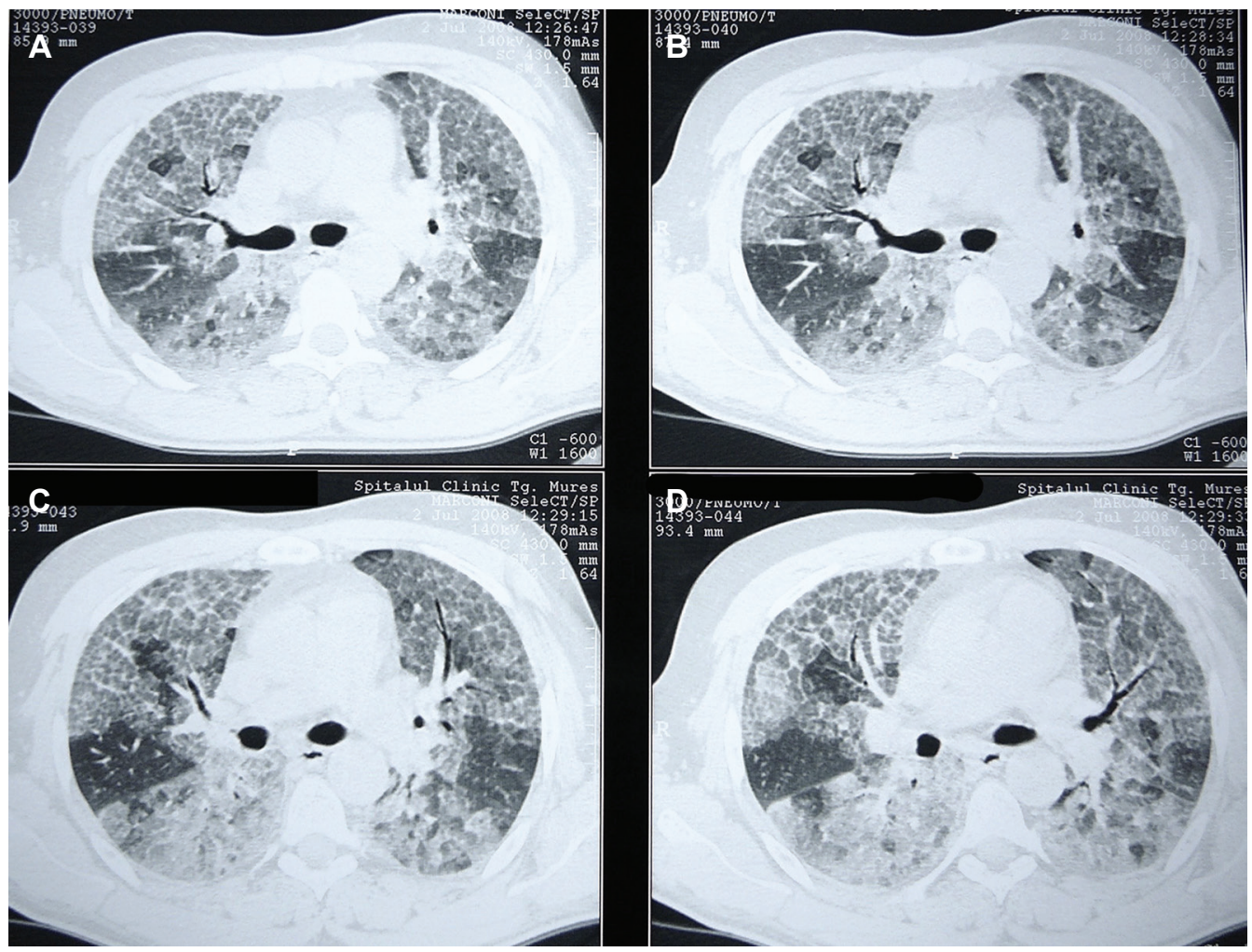

Figure 7. Case 2: CT scan before admission. 
Then both lungs were consecutively washed by WLL 3 weeks apart, with excellent immediate evolution, both clinical and radiological.

Chest film showed great improvement after 3 months (Figure 9). Further exposure to silica was avoided, and no relapse occurred after years.

Conclusion in Case 2: extremely severe form of secondary PAP probably related to professional exposure to silica dust; difficult therapeutic approach due to severity of the respiratory failure and left spontaneous pneumothorax; excellent results after only one WLL on each lung; good prognosis because of cessation of exposure.

\section{Case 3}

A 31-year-old non-smoker woman, with no professional exposure, who was diagnosed with an interstitial lung disease in 2011 which proved to be PAP after surgical lung biopsy from lingula.

She had multiple WLL on both the lungs because she had symptoms (dyspnoea on minimal efforts and cough), a reduction in lung volumes (vital capacity at $54 \%$ from predicted, FEV1 at $55 \%$ from predicted), desaturation on 6MWT (from $94 \%$ to $70 \%$ after $6 \mathrm{~min}$ ), LDH was $>1,000 \mathrm{U} / \mathrm{L}$.

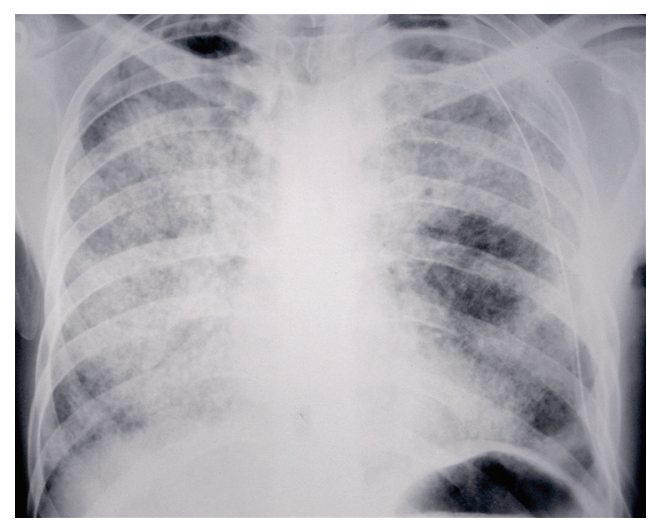

Figure 8. Case 2: Chest X-ray after surgery for left pneumothorax.

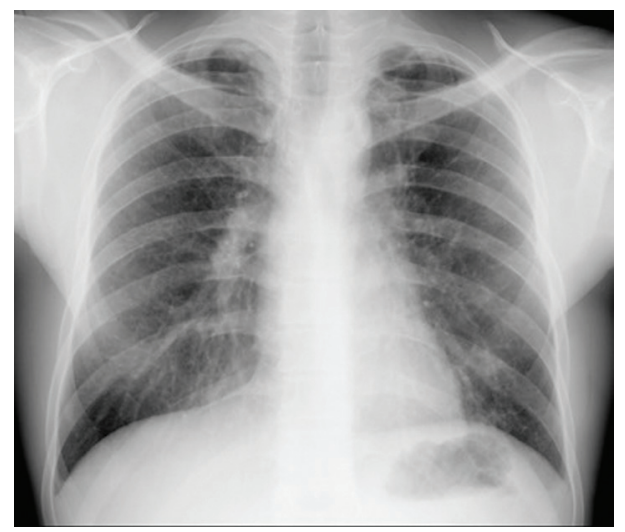

Figure 9. Case 2: Chest X-ray after 3 months.
Despite good immediate results after each WLL, her symptoms and X-ray worsened every 3-6 months, demanding a new WLL (Figures 10-13).

Conclusion in Case 3: A recurrent form of PAP (probably autoimmune form), demanding repeated WLL every 3-6 months; poor prognosis due to frequent relapses in the last 7 years.

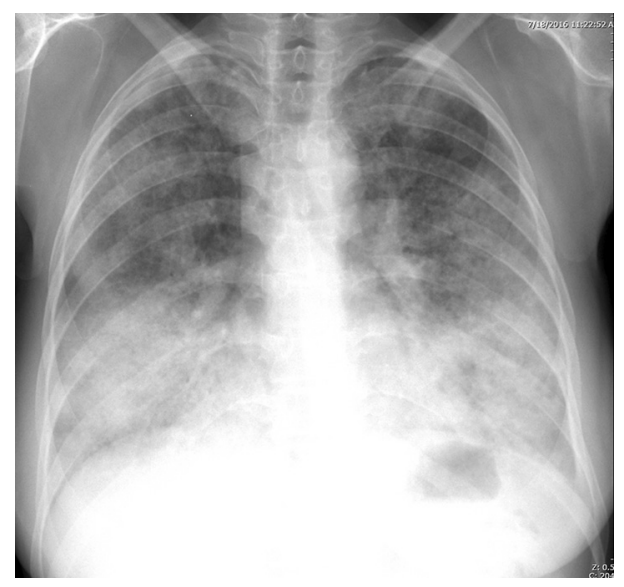

Figure 10. Case 3: Chest X-ray at diagnosis.

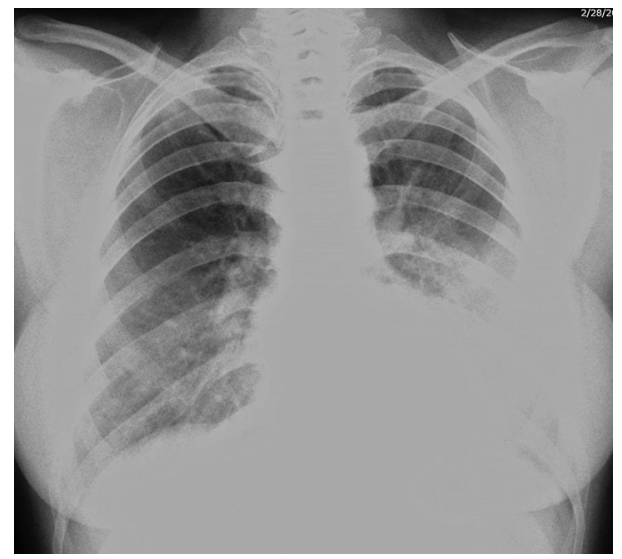

Figure 11. Case 3: Chest $\mathrm{X}$-ray after 2 years.

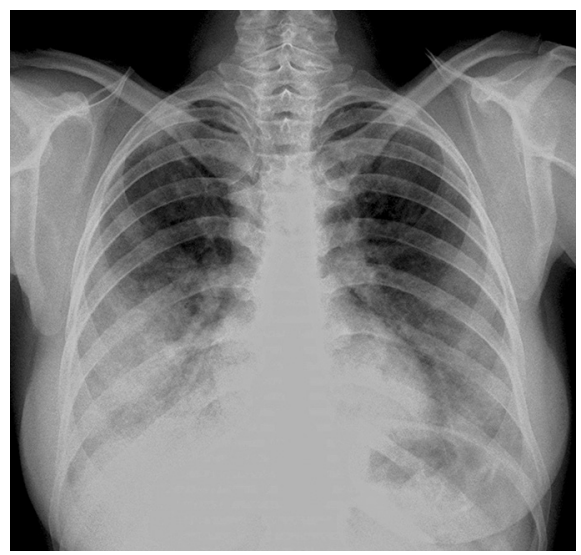

Figure 12. Case 3: Chest X-ray after 4 years. 


\section{Case 4}

A 52-year-old non-smoker male with no professional exposure who was addressed to the pneumology department for dry cough and mild dyspnoea on exertion.

Chest X-ray showed bilateral alveolar opacities in both the lungs with lower lobe predominance (Figure 14).

Blood tests showed polycythaemia $(\mathrm{Hb}=18.50 \mathrm{~g} / \mathrm{dL}$; $\mathrm{Ht}=54.2 \%)$, elevated LDH (880 U/L), no inflammatory syndrome, number of leucocytes in a normal range.

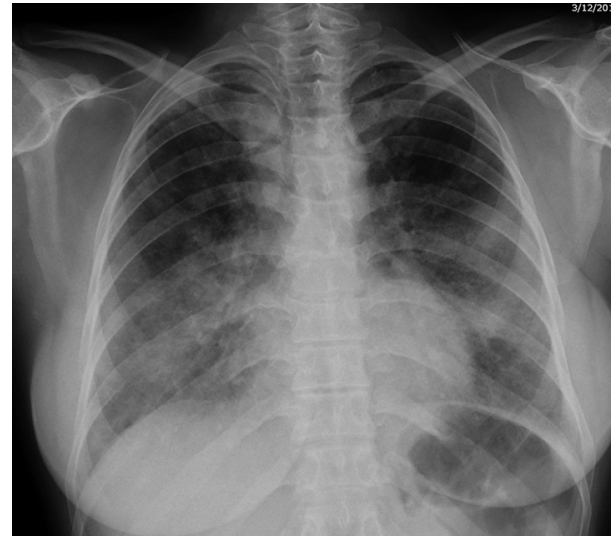

Figure 13. Case 3: Chest X-ray after 7 years.
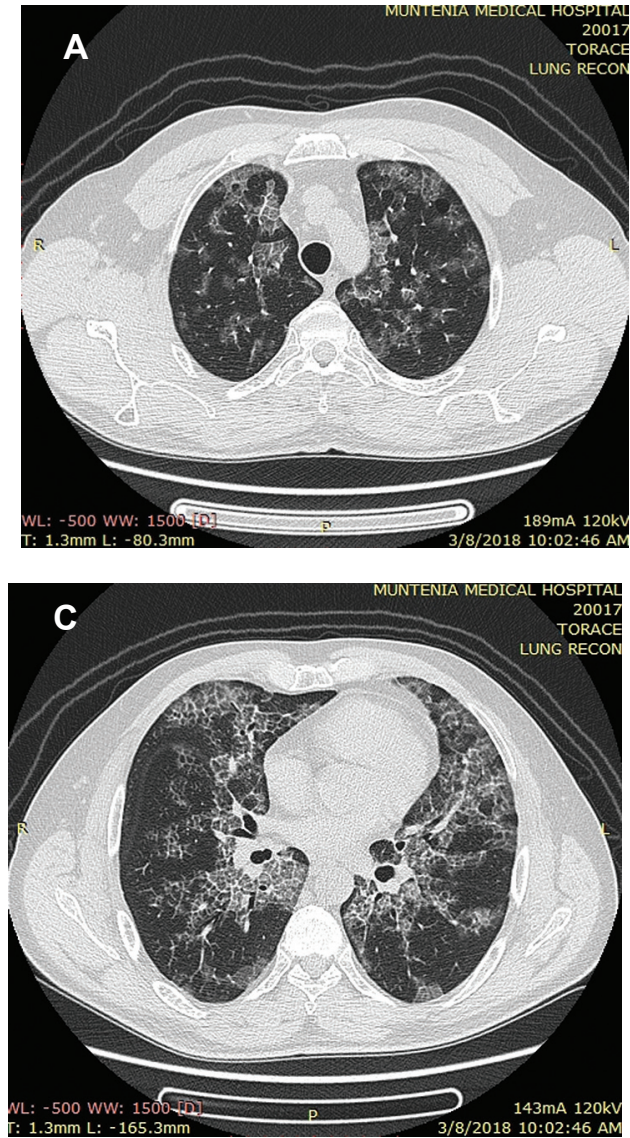

Figure 15. (A-D). Case 4: CT scan at diagnosis.
Pulmonary function tests showed normal volumes and capacities, but low DLco (65\% from predicted).

The 6MVT showed desaturation on effort (from 95\% to $84 \%$ ). Thoracic CT scan revealed widespread "crazy-paving" together with normal areas, giving to clinician a high suspicion of PAP (Figure 15A-D).

Bronchoalveolar lavage was done showing a milky fluid with abundant PAS-positive material, supporting the diagnosis of PAP.

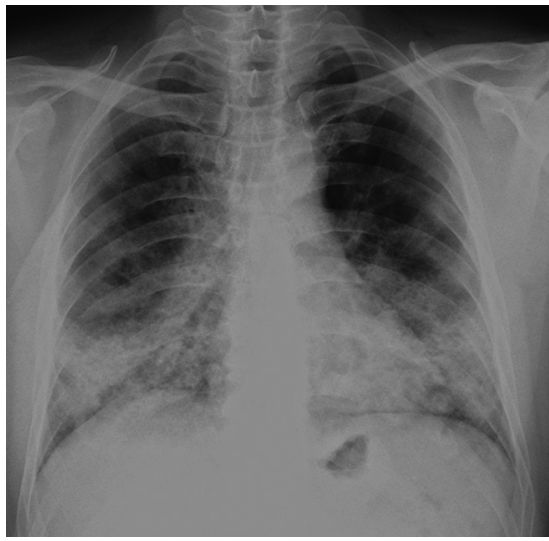

Figure 14. Case 4: Chest X-ray at diagnosis of PAP.
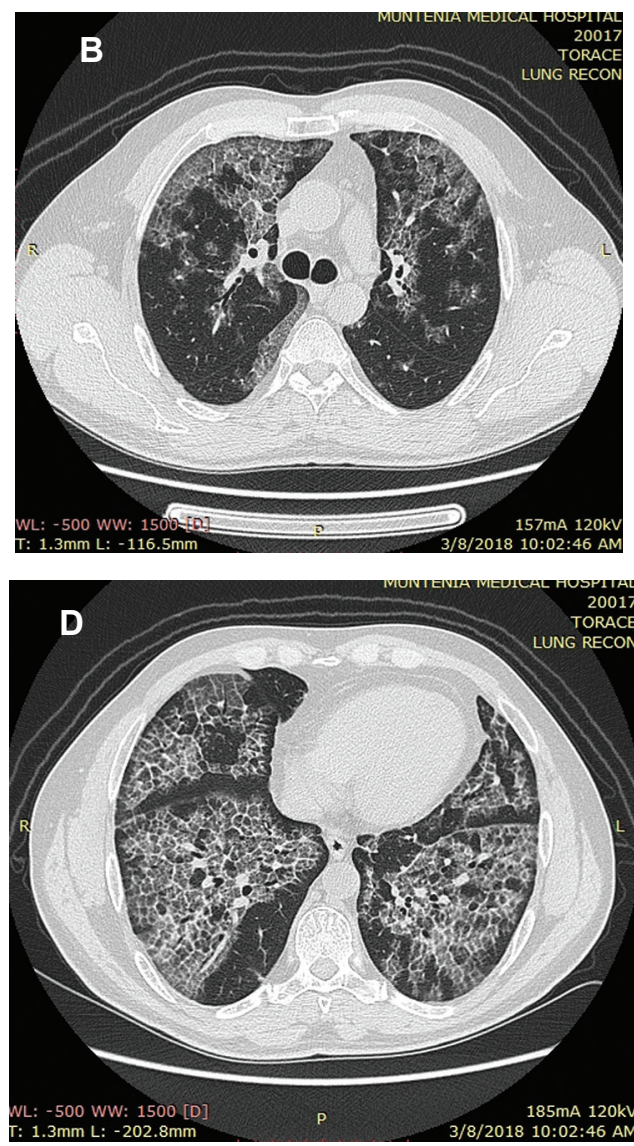
A first WLL was done on the left lung with $15 L$ of saline, with good results.

After discharge from our hospital, the patient was evaluated in other services and haematologic diseases or other solid organ tumours were excluded.

In the next 10 months, the patient's respiratory condition worsened, so after 6 months from diagnosis he already had signs of chronic respiratory failure; he had a second and a third WLL with a slight improvement and was discharged from hospital with oxygen at home.

In 4 months, he was admitted again, with severe hypoxemic respiratory failure $\left(\mathrm{SaO}_{2}=75 \%\right.$ in room air), frequent cough, orthopnoea, with bilateral inspiratory crackles. Chest X-ray (Figure 16) and CT scan (Figure 17A-D) showed impressive worsening, both the lungs are being occupied by a "crazypaving" pattern, with almost no normal areas. He needed
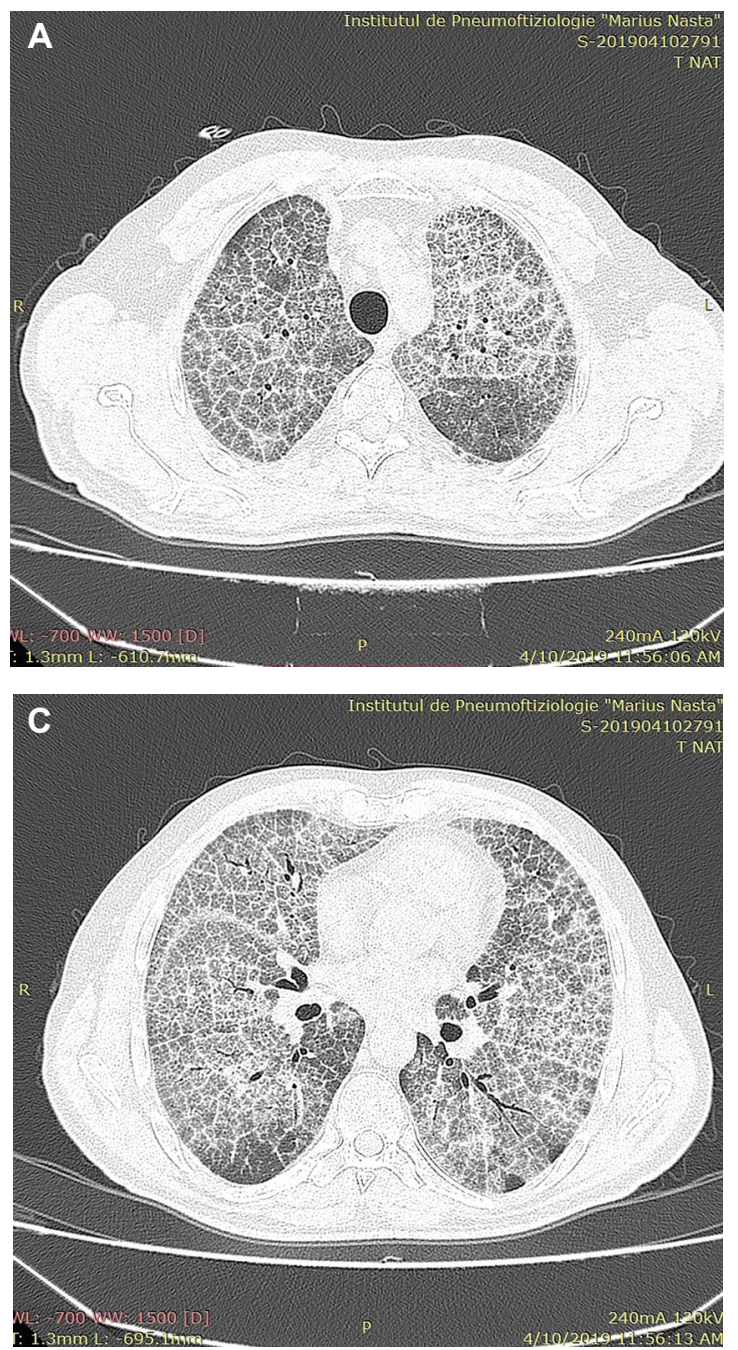

Figure 17. (A-D). Case 4: CT scan after 13 months from diagnosis.

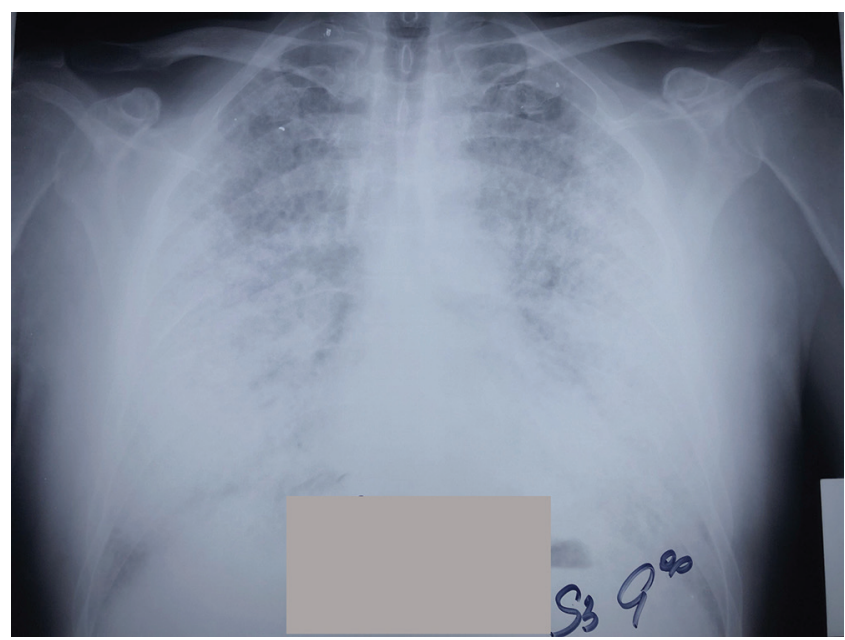

Figure 16. Case 4: Chest X-ray after 13 months from diagnosis.
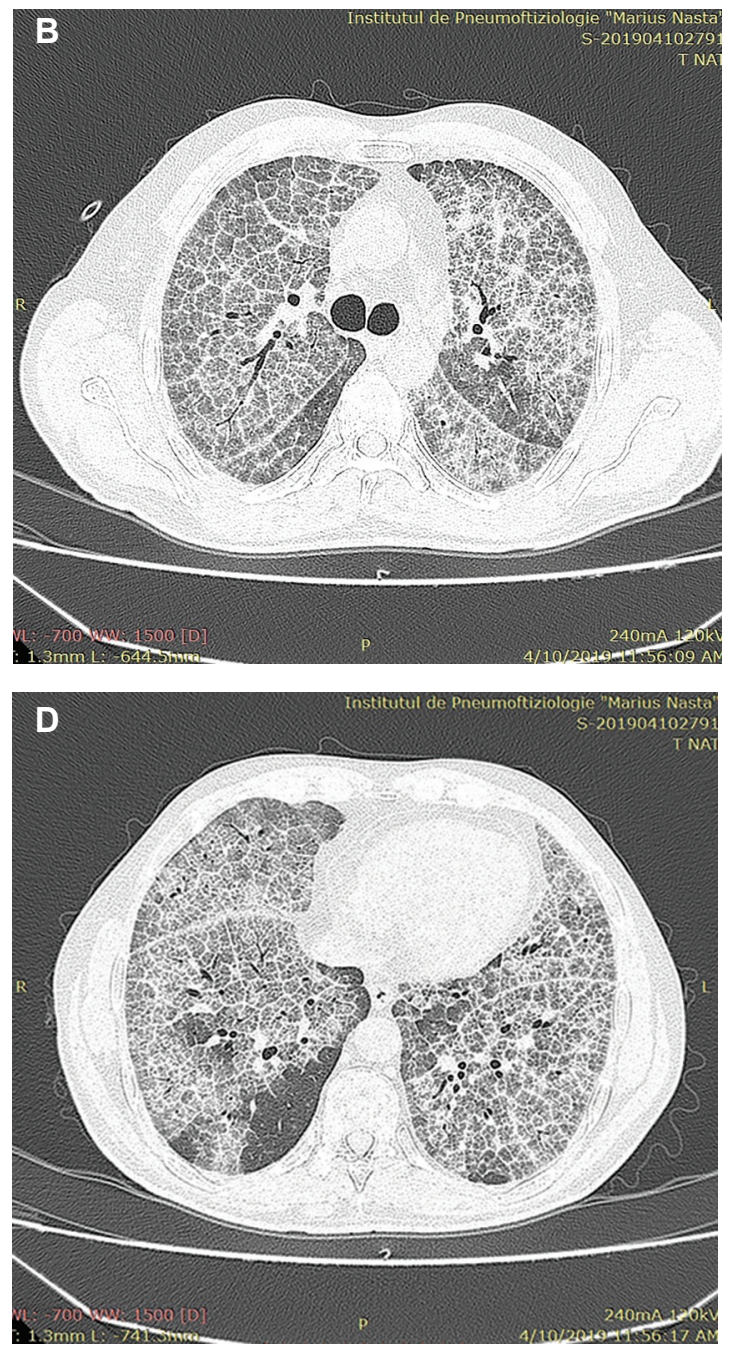
supplemental oxygen at high flow (reservoir-mask, high flow nasal cannula) to maintain $\mathrm{SaO}_{2}$ around $90 \%$. His $\mathrm{PaO}_{2}$ was $<50 \mathrm{mmHg}$ in room air, with an elevated alveolar-arterial difference.

The autoantibodies against GM-CSF were positive $(26 \mathrm{mg} / \mathrm{mL})$, which proved the autoimmune nature of PAP.

He had several successive WLL on both lungs, but the patient's condition was not much better despite its apparent usage (Figure 18 shows the fluid at the beginning and the end of WLL, much improved). He became bed-ridden and needed someone else to take care of him.

In front of this dramatic situation, we addressed other therapies, suitable for autoimmune PAP non-responsive to WLL: he had 5 days of plasmapheresis, followed by therapy with inhaled GM-CSF (Sargramostim 250 mg/ day) for 15 days. A slight improvement was noted (better oxygenation), which allowed the patient to be discharged from the hospital, with oxygen at home. There, he continued to feel better, he obtained $\mathrm{SaO}_{2}>90 \%$ with only 5-6 L/ min of oxygen and he could walk a short distance around the bed. This encouraged us to have a second session of plasmapheresis, followed by inhaled Sargramostim $250 \mathrm{mg} /$ day for another 15 days. With this therapy, his condition continued to become better, and the last evaluation showed marked clinical improvement $\left(\mathrm{SaO}_{2}=95 \%\right.$ with $3 \mathrm{~L} / \mathrm{min}$ $\mathrm{O}_{2}$ through a nasal cannula) and also a radiological one (Figure 19).

Conclusion in Case 4: extremely severe form of autoimmune PAP, refractory to repeated WLL; good response to alternative therapies (plasmapheresis, inhaled GM-CSF). Future concerns: how stable is this improvement? where to get from GM-CSF on a long-term basis, as it is an off-label prescription?

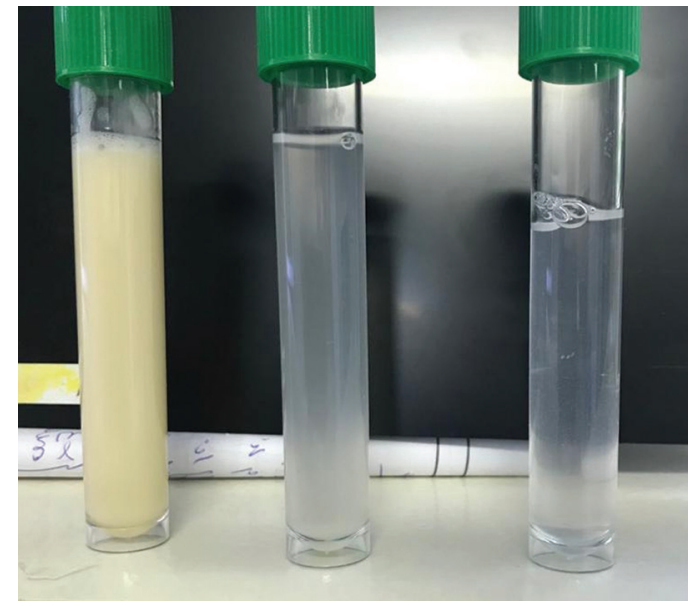

Figure 18. Case 4: Lavage fluid at the beginning and the end of WLL.

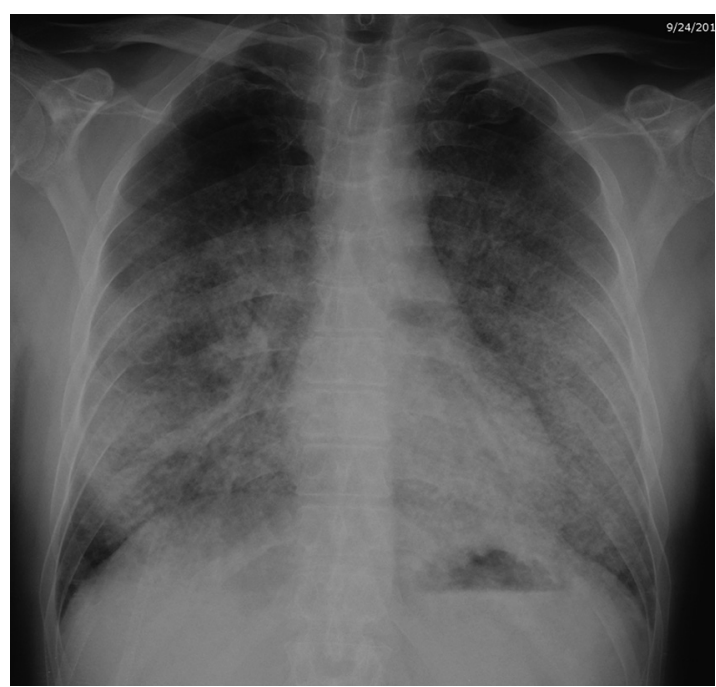

Figure 19. Case 4: Chest X-ray after two sessions of plasmapheresis and inhaled Sargramostim.

\section{Conclusions}

PAP is a heterogenic disease with unpredictable evolution, from spontaneous remission to death due to chronic respiratory failure or infections.

Considering this, if there is no indication for WLL (see above), patients should be followed-up to see whether the spontaneous evolution of the disease occurs.

Autoimmune PAP is the most frequent form; generally, it has a better prognosis than secondary PAP, with a good response to WLL.

Some cases need only one bilateral session of WLL, while others relapse frequently and need repeated WLL, being followed-up for years.

Smoking history, elevated serum LDH and KL-6 seem to predict a more severe disease with the risk of relapse and the need for repeated WLL.

\section{Ethics approval and consent to participate}

Informed consent for publication was obtained from all patients.

\section{Competing interests}

The authors declare that they have no competing interests. 


\section{References}

1. Borie R, Danel C, Debray M-P, Taille C, Dombret M-C, Aubier M, et al. Pulmonary alveolar proteinosis. The European Respiratory Review. 2011;20(120): 98-107.

2. Rosen SH, Castleman B, Liebow AA. Pulmonary alveolar proteinosis. The New England Journal of Medicine. 1958:258(23): 1123-1142.

3. Inoue Y, Trapnell BC, Tazawa R, Arai T, Takada T, Hizawa N, et al. Characteristics of a large cohort of patients with autoimmune pulmonary alveolar proteinosis in Japan. American Journal of Respiratory and Critical Care Medicine. 2008;177: 752762.

4. Bonella F, Bauer PC, Griese M, Ohshimo S, Guzman J, Costabel U. Pulmonary alveolar proteinosis: new insights from a singlecenter cohort of 70 patients. Respiratory Medicine. 2011:105(12): 1908-1916.

5. Whitsett JA, Wert SE, Weaver TE. Alveolar surfactant homeostasis and the pathogenesis of pulmonary disease. Annual Review of Medicine. 2010;61: 105-119.

6. Shibata Y, Berclaz PY, Chroneos ZC, Yoshida M, Whitsett JA, Trapnell BC. GM-CSF regulates alveolar macrophage differentiation and innate immunity in the lung through PU.1. Immunity. 2001;15: 557-567.

7. Kitamura T, Tanaka N, Watanabe J, Uchida, Kanegasaki S, Yamada $\mathrm{Y}$, et al. Idiopathic pulmonary alveolar proteinosis as an autoimmune disease with neutralizing antibody against granulocyte/macrophage colony-stimulating factor. The Journal of Experimental Medicine. 1999;190: 875-880.

8. KitamuraT, UchidaK, TanakaN, TsuchiyaT, Watanabe J, YamadaY, et al. Serological diagnosis of idiopathic pulmonary alveolar proteinosis. American Journal of Respiratory and Critical Care Medicine. 2000;162:658-662.

9. Costabel U, Guzman J. Pulmonary alveolar proteinosis: a new autoimmune disease. Sarcoidosis Vasculitis and Diffuse Lung Disease. 2005;22(Suppl 1): 67S-73S

10. Dirksen U, Hattenhorst U, Schneider P, Schroten H, Göbel U, Böcking $A$, et al. Defective expression of granulocyte-macrophage colony-stimulating factor/interleukin-3/interleukin-5 receptor common beta chain in children with acute myeloid leukemia associated with respiratory failure. Blood. 1998;92: 1097-1103.

11. Ishii H, Seymour JF, Tazawa R, Inoue $Y$, Uchida N, Nishida A, et al. Secondary pulmonary alveolar proteinosis complicating myelodysplastic syndrome results in worsening of prognosis: a retrospective cohort study in Japan. BMC Pulmonary Medicine. 2014;14: 37.

12. Ishii H, Tazawa R, Kaneko C, Saraya T, Inoue $Y$, Hamano E, et al. Clinical features of secondary pulmonary alveolar proteinosis: pre-mortem cases in Japan. European Respiratory Journal. 2011;37(2): 465-468.
13. Heppleston AG, Wright NA, Stewart JA. Experimental alveolar lipo-proteinosis following the inhalation of silica. The Journal of Pathology. 1970;101(4): 293-307.

14. Cummings KJ, Donat WE, Ettensohn DB, Roggli VL, Ingram $P$, Kreiss K. Pulmonary alveolar proteinosis in workers at an indium processing facility. American Journal of Respiratory and Critical Care Medicine. 2010;181(5): 458-464.

15. Suzuki T, Sakagami T, Young LR, Carey BC, Wood RE, Luisetti M, et al. Hereditary pulmonary alveolar proteinosis: pathogenesis, presentation, diagnosis, and therapy. American Journal of Respiratory and Critical Care Medicine. 2010;182: 1292-1304.

16. Suzuki T, Sakagami T, Rubin BK, Nogee LM, Wood RE, Zimmerman SL, et al. Familial pulmonary alveolar proteinosis caused by mutations in CSF2RA. The Journal of Experimental Medicine. 2008;205(12): 2703-2710.

17. Tredano M, Griese M, Brasch F, Schumacher S, de Blic J, Marque S, et al. Mutation of SFTPC in infantile pulmonary alveolar proteinosis with or without fibrosing lung disease. American Journal of Medical Genetics Part A. 2004;126(1): 18-26.

18. Shah PL, Hansell D, Lawson PR, Reid KB, Morgan C. Pulmonary alveolar proteinosis: clinical aspects and current concepts on pathogenesis. Thorax. 2000;55(1): 67-77.

19. Goldstein LS, Kavuru MS, Curtis-McCarthy P, Christie HA, Farver C, Stoller JK. Pulmonary alveolar proteinosis: clinical features and outcomes. Chest. 1998;114(5): 1357-1362.

20. Lee KN, Levin DL, Webb WR, Chen D, Storto ML, Golden JA. Pulmonary alveolar proteinosis: high-resolution CT, chest radiographic, and functional correlations. Chest. 1997;111(4): 989-995

21. Holbert JM, Costello P, Li W, Hoffman RM, Rogers RM. CT features of pulmonary alveolar proteinosis. American Journal of Roentgenology. 2001;176: 1287-1294.

22. Johkoh $\mathrm{T}$, Itoh $\mathrm{H}$, Muller NL, Ichikado K, Nakamura H, Ikezoe $\mathrm{J}$, et al. Crazy-paving appearance at thin-section CT: spectrum of disease and pathologic findings. Radiology. 1999;211: 155-160.

23. Ishii H, Trapnell BC, Tazawa R, Inoue Y, Akira M, Kogure Y, et al. Comparative study of high-resolution CT findings between autoimmune and secondary pulmonary alveolar proteinosis. Chest. 2009;136(5): 1348-1355.

24. Rossi SE, Erasmus JJ, Volpacchio M, Franquet T, Castiglioni T, McAdams HP. "Crazy-paving" pattern at thin-section CT of the lungs: radiologic-pathologic overview. Radiographics. 2003;23(6): 1509-1519.

25. Costabel U, Guzman J, Bonella F, Oshimo S. Bronchoalveolar lavage in other interstitial lung diseases. Seminars in Respiratory and Critical Care Medicine. 2007;28(5): 514-524.

26. Milleron BJ, Costabel U, Teschler H, Ziesche R, Cadranel JL, Matthys $\mathrm{H}$, et al. Bronchoalveolar lavage cell data in alveolar proteinosis. American Review of Respiratory Disease. 1991;144: 1330-1332. 
27. Delaval P, Brinchault G, Corre R, Jouneau S, Meunier C, Briens E. Lipoproteinose alveolaire pulmonaire [Pulmonary alveolar phospholipoproteinosis]. Revue de Pneumologie Clinique. 2005;61: 186-192.

28. Bonfield TL, Russell D, Burgess S, Malur A, Kavuru MS, Thomassen MJ. Autoantibodies against granulocyte macrophage colony-stimulating factor are diagnostic for pulmonary alveolar proteinosis. American Journal of Respiratory Cell and Molecular Biology. 2002;27(4): 481-486.

29. Uchida K, Nakata K, Trapnell BC, Terakawa T, Hamano E, Mikami A, et al. High-affinity autoantibodies specifically eliminate granulocyte-macrophage colony-stimulating factor activity in the lungs of patients with idiopathic pulmonary alveolar proteinosis. Blood. 2004;103(3):1089-1098.

30. Uchida K, Nakata K, Suzuki T, Luisetti M, Watanabe M, Koch DE, et al. Granulocyte/macrophage colony-stimulating factor autoantibodies and myeloid cell immune functions in healthy individuals. Blood. 2009;113: 2547-2556.

31. Sergeeva A, Ono Y, Rios R, Molldrem JJ. High titer autoantibodies to GM-CSF in patients with AML, CML and MDS are associated with active disease. Leukemia. 2008:22(4): 783-790.

32. Ishikawa N, Hattori N, Yokoyama A, Kohno N. Utility of KL-6/ MUC1 in the clinical management of interstitial lung diseases. Respiratory Investigation. 2012;50(1): 3-13.

33. Bonella F, Campo I. Pulmonary alveolar proteinosis. Pneumologia. 2014;144: 147-155.

34. Leth S, Bendstrup E, Vestergaard H, Hilberg O. Autoimmune pulmonary alveolar proteinosis: treatment options in year 2013. Respirology 2013;18(1): 82-91.

35. Luisetti M. Call for an international survey on therapeutic lavage for pulmonary alveolar proteinosis. European Respiratory Journal. 2012;39(4): 1049.

36. Ramirez J, Schultz RB, Dutton RE. Pulmonary alveolar proteinosis: a new technique and rationale for treatment. Archives of Internal Medicine. 1963;112: 419-431.

37. Seymour JF, Presneill JJ, Schoch OD, Downie GH, Moore PE, Doyle IR, et al. Therapeutic efficacy of granulocyte-macrophage colony-stimulating factor in patients with idiopathic acquired alveolar proteinosis. American Journal of Respiratory and Critical Care Medicine. 2001;163(2): 524-531.
38. Venkateshiah SB, Yan TD, Bonfield TL, Thomassen MJ, Meziane M, Czich C, et al. An open-label trial of granulocyte macrophage colony stimulating factor therapy for moderate symptomatic pulmonary alveolar proteinosis. Chest. 2006;130(1): 227-223.

39. Wylam ME, Ten R, Prakash UB, Nadrous HF, Clawson ML, Anderson PM. Aerosol granulocyte-macrophage colonystimulating factor for pulmonary alveolar proteinosis. European Respiratory Journal. 2006;27(3): 585-593.

40. Tazawa R, Trapnell BC, Inoue Y, Arai T, Takada T, Nasuhara Y, et al. Inhaled granulocyte/macrophage-colony stimulating factor as therapy for pulmonary alveolar proteinosis. American Journal of Respiratory and Critical Care Medicine. 2010;181(12): 1345-1354.

41. Tanner LM, Kurko J, Tringham M, Aho H, Mykkänen J, Näntö-Salonen K, et al. Inhaled sargramostim induces resolution of pulmonary alveolar proteinosis in lysinuric protein intolerance. JIMD Reports. 2017;34: 97-104.

42. Onkouchi $\mathrm{S}$, Akasara $\mathrm{K}$, Ichiwata $\mathrm{T}$, Hisata $\mathrm{S}$, lijima $\mathrm{H}$, Takada T, et al. Sequential granulocyte-macrophage-colonystimulating factor after whole lung lavage for pulmonary alveolar proteinosis for pulmonary alveolar proteinosis. A report of five intractable cases. Annals of the American Thoracic Society. 2017; 14: 1298.

43. Tazawa R, Ueda T, Abe M, Tatsumi K, Eda R, Kondoh S, et al. Inhaled GM-CSF for Pulmonary Alveolar Proteinosis. The New England Jorunal of Medicine. 2019;381(10): 923-932.

44. Kavuru MS, Bonfield TL, Thomassen MJ. Plasmapheresis, GM-CSF, and alveolar proteinosis. American Journal of Respiratory and Critical Care Medicine. 2003;167(7): 1036-1037.

45. Luisetti M, Rodi G, Perotti C, Campo I, Mariani F, Pozzi E, et al. Plasmapheresis for treatment of pulmonary alveolar proteinosis. European Respiratory Journal. 2009;33(5): 1220-1222.

46. Kavuru MS, Malur A, Marshall I, Barna BP, Meziane M, Huizar I, et al. An open-label trial of rituximab therapy in pulmonary alveolar proteinosis. European Respiratory Journal. 2011;38(6): 1361-1367.

47. Sovez B, Borie R, Menard C, Cadranel J, Chavez L, Cottin V, et al. Rituximab for auto-immune alveolar proteinosis, a real life cohort. Respiratory Research. 2018;19: 74.

48. Stoica R, Macri A, Cordos I, Bolca C. Whole lung lavage for pulmonary alveolar proteinosis after surgery for spontaneous pneumothorax. Journal of Medicine and Life. 2012;5(3): 311-315. 